\title{
HIV diagnosed after 50 years of age
}

\author{
Jacqueline M. McMillan MD, Leah H. Rubin PhD, M. John Gill MD
}

Cite as: CMAJ 2020 March 9;192:E255. doi: 10.1503/cmaj.191677

1 In 2017, 22.9\% of new HIV diagnoses in Canada were in people aged 50 years and older ${ }^{1}$

Similar rates of new diagnoses were reported in the United States in 2017 $(17.1 \%)$ and in Europe in 2015 (17.3\%). ${ }^{2}$ Screening for HIV is disproportionately low in adults 50 years and older, with a screening rate of only $25 \%$ in the US in 2009. ${ }^{3}$ This is likely because older adults perceive that they are at low or no risk for HIV exposure. ${ }^{3}$ According to the Public Health Agency of Canada's HIV Screening and Testing Guide (https://www.canada.ca/en/ public-health/services/hiv-aids/hiv-screening-testing-guide.html\#c1), individuals who are/have been sexually active and have never been tested for HIV should be tested at least once.

2

Older adults report different sexual behaviours leading to differential HIV risk than younger individuals

Older adults in the largest risk category for HIV are those who have heterosexual sex (42\%-48\%), whereas younger adults in the largest risk category are men who have sex with men $(38 \%-45 \%))^{2,4}$

\section{3}

\section{The reason for HIV testing often differs by age}

One study reported $70 \%$ of new diagnoses in people aged 50 years and older occurred in hospital compared with $42 \%$ in people aged $18-49$ years. ${ }^{4}$ Another study reported that in more than half of people aged 50 and older screening was performed solely on the recommendation of a health care provider. ${ }^{3}$

At diagnosis, the CD4 T-cell count is lower in older than in younger adults (median $0.097-0.24 \mathrm{v} .0 .307-0.394 \times 10^{9} / \mathrm{L}$ [97-240 v. 307-394 cells/ $\mu \mathrm{L}])^{2,4}$

In one study, $70 \%$ of individuals aged 50 or older at diagnosis had concurrent AIDS. ${ }^{4}$ In the same study, older age was associated with a threefold increase in odds of late HIV diagnosis, defined as CD4 T-cell count $<0.2 \times 10^{9} / \mathrm{L}$ $\left(<200\right.$ cells $/ \mu \mathrm{L}$ ) or AIDS-defining illness. ${ }^{4}$

\section{Older adults are more likely to adhere to HIV treatment than younger adults once antiretroviral therapy is initiated ${ }^{5}$} More frequent HIV screening will enable earlier diagnosis and, consequently, earlier initiation of treatment. As the HIV population ages, providers should also screen for and manage age-related comorbidities.

\section{References}

1. Haddad N, Li J, Totten S, et al. HIV in Canada - surveillance report, 2017. Can Commun Dis Rep 2018;44:348-56.

2. Tayoschi TDJ, Pharris A. New HIV diagnoses among adults aged 50 years or older in 31 European countries, 2004-15: an analysis of surveillance data. Lancet HIV 2017;4:e514-21.

3. Adekeye OA, Heiman HJ, Onyeabor OS, et al. The new invincibles: HIV screening among older adults in the US. PLoS One 2012;7:e43618.

4. Ellman TM, Sexton ME, Warshafsky D, et al. A forgotten population: older adults with newly diagnosed HIV. AIDS Patient Care STDS 2014;28:530-6.

5. Ghidei L, Simone MJ, Salow MJ, et al. Aging, antiretrovirals, and adherence: a meta analysis of adherence among older HIV-infected individuals. Drugs Aging 2013;30:809-19.

Competing interests: In last 3 years M. John Gill has served or been asked to serve as an ad hoc member of the national HIV advisory boards of Merck, Gilead and ViiV. No other competing interests were declared.

This article has been peer reviewed.

Affiliations: Department of Medicine (McMillan, Gill), University of Calgary, Calgary, Alta.; School of Medicine (Rubin), Johns Hopkins University, Baltimore, Md.

Correspondence to: Jacqueline McMillan, jacqueline.mcmillan@ahs.ca 